\title{
FACTORS AFFECTING THE ARRIVAL TIME TO HOSPITAL OF PATIENTS WITH ACUTE ISCHEMIC STROKE
}

\author{
Haki Cemile, ${ }^{1}$ Cetiner Mustafa, ${ }^{2}$ Kaya Halil $^{3}$ \\ ${ }^{1}$ University of Health Sciences, Bursa Yuksek Ihtisas Training and Research Hospital, \\ Department of Neurology, Bursa, Turkey \\ ${ }^{2}$ Kutahya University of Health Sciences Faculty of Medicine, Department of Neurology, Kutahya, Turkey \\ ${ }^{3}$ University of Health Sciences, Bursa Yuksek Ihtisas Training and Research Hospital, \\ Department of Emergency Medicine, Bursa, Turkey
}

Primljen/Received 08. 05. 2020. god.

Abstract: Objective: It is known that intravenous thrombolytic therapy in ischemic stroke is beneficial in selected patients who arrived within the first 4.5 hours after the onset of the symptoms and the effectiveness of the treatment depends on early arrival to the hospital. The more patients arrival to the hospital within this time zone, the more they will have the chance to receive thrombolytic therapy. This study aims to investigate the factors that cause delay in the arrival of patients with ischemic stroke to the hospital.

Methods: Patients diagnosed with acute ischemic stroke who applied to the neurology outpatient clinic and emergency room between February and May 2019 were included in the study. A direct interview survey was conducted to investigate the factors that delay the arrival to patients or relatives of the patients arrival to Bursa Yuksek Ihtisas Training and Research Hospital due to acute stroke. According to the time of arrival to the hospital after the onset of stroke symptoms, patients were classified as early ( $\leq 4.5$ hours) and late arrival ( $>4.5$ hours). Based on this grouping, factors causing delay in patients' access to hospital were compared statistically.

Results: A total of 251 patients and / or patient relatives who arrived to the emergency and neurology outpatient clinic were interviewed. Of the 251 patients included in the study, $119(47.4 \%)$ were female and the mean age was 70 (34-94) years. Approximately 72.5\% of the patients were arrived in the first 4.5-hour slice after the onset of stroke symptoms. Factors causing late arrival were determined as being female, having low NIHSS score and not using ambulance in transportation.

Conclusion: Due to the delay in arrival of $27.5 \%$ of the patients, there is no chance to apply thrombolytic
Prihvaćen/Accepted 15. 06. 2020. god.

therapy to eligible ones. The factors resulting in the delay were discovered as female gender, low severity of the stroke and transportation without ambulance. In this respect, community-oriented trainings are required.

Key words: Ischemic stroke, late arrival, emergency room, thrombolytic therapy.

\section{INTRODUCTION}

Stroke is one of the leading causes of death and disability worldwide. It is known that intravenous (IV) administration of thrombolytic therapy is helpful in selected patients in the first 4.5 hours following the onset of the symptoms and the earlier the treatment is started, the more effective it is. The more patients that arrived to the hospital within this time zone, the more patients will have the chance to receive thrombolytics $(1,2,3)$.

The delay from the onset of stroke to arrival at the hospital reduces the rate of these patients to be treated with thrombolytic and/or mechanical thrombectomy. For this reason, the effect of a variety of factors in the arrival time to hospital of stroke patients were examined in previous studies. These factors include living alone, stroke onset time, age, gender, education level, place of arrival at the hospital, income level, distance to the hospital, stroke symptoms, stroke risk factors, level of consciousness, way to reach the hospital, National Health Stroke Scale (NIHSS), contact with the local doctor, recognition of stroke symptoms by healthcare professionals, patients and the relatives. It has been observed that the time of arrival to the hospital varies according to the development level of the countries, geographic, sociodemographic and organizational factors (4-21). In our study, we aimed to investigate the 
causes leading to delay in the arrival of stroke patients to the hospital.

\section{MATERIAL AND METHODS}

This study included patients older than 18 years who arrived to the neurology outpatient clinic and emergency room between February and May 2019, presented stroke symptoms compatible with neuroimaging and were diagnosed with acute ischemic stroke. Patients with intracerebral hemorrhage and in-hospital stroke were excluded from the study. Stroke onset time was recorded as the time of appearance of stroke symptoms. In the wake-up strokes, the moment when the patient was last seen as healthy was evaluated as the stroke onset time. A questionnaire was filled in by interviewing each patient or the relative who agreed to participate in the study. Using the NIHSS, stroke symptom onset, hospital arrival time, age, gender, level of education and financial status, stroke severity at arrival were determined. Stroke onset time was divided into two intervals as day (07:00-19:00) and night time (19:00-07: $00)$. The distance patients covered was determined using regional road maps. Neurological deficits during discharge were evaluated with modified ranking scale (mRS) scores. Having mRS $\leq 2$ during discharge was recorded as a good functional outcome and $\mathrm{mRS}>2$ as bad. Education levels of the patients were classified as secondary education or less, high school and university graduate. Income status was grouped as low, medium and high according to the economic situation perceived by the patient.

Whether the hospital arrival was direct or from another hospital, previous knowledge of the patients and their relatives about thrombolytic therapy was questioned and patients treated with thrombolytic therapy were recorded. As a result of the neurological examination, the consciousness levels of the patients were determined as conscious and unconscious (somnolence /stupor). Stroke symptoms were recorded as aphasia, dysarthria, hemianopsia, hemiparesis, hemihipoesthesia. Vascular risk factors, hypertension, diabetes mellitus (DM), hyperlipidemia, coronary artery disease (CAD), atrial fibrillation (AF), smoking and family history of stroke were determined. Transportation to the hospital, by ambulance or other private vehicles was questioned. According to the time of arrival to the hospital after the onset of stroke symptoms, patients were grouped as early ( $\leq 4.5$ hours) and late arrival ( $>4.5$ hours). Factors related to the delay in the arrival of patients were compared statistically based on this grouping. The study was approved by Bursa Yuksek Ihtisas Training and Research Hospital Ethics Committee with the decision numbered 2011-KAEK-25 2019 / 02-26.

\section{Statistical Analysis}

Data were presented as the number of patients, percentage, mean, standard deviation and median, and the suitability of the data to normal distribution was evaluated. The variables that fit the normal distribution are given as mean \pm standard deviation and those that do not fit the normal distribution are given as median (minimum-maximum). Parametric methods were used to relate data that match normal distribution, and nonparametric statistical methods were utilized to compare data that did not match normal distribution.

Parametric data in independent groups were compared with t-test and non-parametric data with Mann Whitney $U$ test. The significance of the difference between categorical variables was evaluated by chi-square and Fisher's exact test. Multivariate logistic regression analysis was applied for variables that were statistically significant $(\mathrm{p}<0.05)$ in univariate analyzes. Data were analyzed at $95 \%$ confidence interval. All statistical analysis was carried out using SPSS 24.0 (IBM Corp.; Armonk, NY, USA) programme.

\section{RESULTS}

Of the 251 patients included in the study, 132 were male $(52.6 \%), 119(47.4 \%)$ were female, and the mean age was 70 years (34-94). 182 patients (72.5\%) applied to the hospital in the first 4.5 hours of stroke after the onset of the symptoms. There were 69 patients $(27.5 \%)$ applying over the first 4.5 -hour slice. The socio-demographic characteristics of the patients are presented in Table 1. Stroke symptoms were most common during

Table 1. Socio-demographic characteristics of stroke patients $(n=251)$

\begin{tabular}{|l|c|}
\hline Socio-demographic characteristics & n (\%) \\
\hline Age & $70(34-94)$ \\
\hline Gender & $132(52.6)$ \\
- Male & $119(47.4)$ \\
- Female & \\
\hline Education & $208(82.9)$ \\
- Secondary school or less & $32(12.7)$ \\
- High School & $11(4.4)$ \\
- University & \\
\hline Place of arrival at the hospital & $179(71.3)$ \\
- City & $59(23.5)$ \\
- District & $13(5.2)$ \\
- Country & \\
\hline Income Level & $125(49.8)$ \\
- Low & $120(47.8)$ \\
- Middle & $6(2.4)$ \\
- High & $5(1-160)$ \\
\hline Distance $(\mathrm{km})$ &
\end{tabular}


daytime with 155 patients $(61.8 \%)$. Hemiparesis was the most common stroke symptom in 169 patients (67.3\%). Hypertension was the most common stroke risk factor in 167 patients $(66.5 \%)$. NIHSS averages of the patients at the time of admission were calculated as 4 (1-32). The number of patients transferring to the hospital by ambulance was 160 (63.7\%). Only 16 patients $(6.4 \%)$ knew about the application of thrombolytic therapy priorly. The consciousness of 185 patients $(73.7 \%)$ was normal at the time of admission to the hospital.

The number of patients who applied to our hospital directly was 179 (71.3\%). Good functional outcome

Table 2. Patients'stroke related features $(n=251)$

\begin{tabular}{|l|c|}
\hline Patients' stroke related features & $\mathbf{n}(\mathbf{\%})$ \\
\hline Symptom onset time & \\
- Night (19:00-07:00) & $96(38.2)$ \\
- Day (07:00-19:00) & $155(61.8)$ \\
\hline Symptom door time (min.) & $104(15-5500)$ \\
\hline Stroke Symptoms & \\
- Hemiparesis & $169(67.3)$ \\
- Hemihypoesthesia & $91(36.3)$ \\
- Hemianopsia & $36(14.3)$ \\
- Aphasia & $115(45.8)$ \\
- Dysarthria & $60(23.9)$ \\
\hline Stroke Risk Factors & \\
- Stroke History & $76(30.3)$ \\
- Hypertension & $167(66.5)$ \\
- Smoking & $66(26.3)$ \\
- Diabetes & $90(35.9)$ \\
- Hyperlipidemia & $54(21.5)$ \\
- CAD & $76(30.3)$ \\
- AF & $47(18.7)$ \\
- Family History & $72(28.7)$ \\
\hline NIHSS (During application) & $4(1-32)$ \\
\hline Transfer to Hospital & $179(71.3)$ \\
- Ambulance & $72(28.7)$ \\
\hline - Other & $111(44.3)$ \\
\hline Information about thrombolytic & $91(36.3)$ \\
therapy16 (6.4) & \\
\hline Consciousness Level & $185(73.7)$ \\
- Normal & $19(7.6)$ \\
- Somnolence & \\
- Stupor & \\
\hline Arrival to Hospital & \\
-Direct arrival & \\
-Transfer from another center & \\
\hline mRS (at discharge) & \\
$\leq 2$ & \\
>2 & \\
\hline
\end{tabular}

AF: Atrial fibrillation, CAD: Coronary artery disease, NIHSS, National Institutes of Health Stroke Scale, mRS: modified Rankin Scale
Table 3. Comparison of patients'socio-demographic and clinical characteristics by the time of arrival at the hospital $(n=251)$

\begin{tabular}{|c|c|c|c|}
\hline & \multicolumn{2}{|c|}{ Admission } & \multirow[b]{2}{*}{$\mathbf{P}$} \\
\hline & $\begin{array}{c}(\leq 4,5 \\
\text { hours }), \mathrm{n}= \\
182\end{array}$ & $\left(\begin{array}{c}(>4,5 \text { hours }) t) \\
n=69\end{array}\right.$ & \\
\hline Age & $70(36-92)$ & $68,56 \pm 12.43$ & 0.77 \\
\hline $\begin{array}{l}\text { Gender } \\
\text { - Female }\end{array}$ & $78(42.9)$ & $41(59.4)$ & $0.03 *$ \\
\hline $\begin{array}{l}\text { Education } \\
\text { - Secondary School or less } \\
\text { - High School } \\
\text { - University }\end{array}$ & $\begin{array}{c}151(83) \\
22(12.1) \\
9(4.9)\end{array}$ & $\begin{array}{c}57(82.6) \\
10(14.5) \\
2(2.9)\end{array}$ & 0.70 \\
\hline $\begin{array}{l}\text { Place of arrival to the } \\
\text { hospital } \\
\text { - City } \\
\text { - District } \\
\text { - Country }\end{array}$ & $\begin{array}{c}128(70.3) \\
44(24.2) \\
10(5.5)\end{array}$ & $\begin{array}{c}51(73.9) \\
15(21.7) \\
3(4.3)\end{array}$ & 0.79 \\
\hline $\begin{array}{l}\text { Income Level } \\
\text { - Low } \\
\text { - Medium } \\
\text { - High }\end{array}$ & $\begin{array}{c}83(45.6) \\
94(51.6) \\
5(2.7) \\
\end{array}$ & $\begin{array}{c}42(60.9) \\
26(37.7) \\
1(1.4)\end{array}$ & 0.12 \\
\hline Distance $(\mathrm{km})$ & $5(1-90)$ & $5(2-160)$ & 0.83 \\
\hline $\begin{array}{l}\text { Symptom Onset time } \\
\text { - Day (07:00-19:00) } \\
\text { - Night (19:00-07:00) }\end{array}$ & $\begin{array}{l}111(61) \\
71(39)\end{array}$ & $\begin{array}{l}44(63.8) \\
25(36.2)\end{array}$ & 0.6 \\
\hline $\begin{array}{l}\text { Stroke Symptoms } \\
\text { - Hemiparesis } \\
\text { - Hemihypoesthesia } \\
\text { - Hemianopsia } \\
\text { - Aphasia } \\
\text { - Dysarthria }\end{array}$ & $\begin{array}{l}129(70.9) \\
64(35.2) \\
28(15.4) \\
90(49.5) \\
49(26.9)\end{array}$ & $\begin{array}{c}40(58) \\
27(39.1) \\
8(11.6) \\
25(13.7) \\
11(15.9)\end{array}$ & $\begin{array}{l}0.06 \\
0.44 \\
0.67 \\
0.08 \\
0.06\end{array}$ \\
\hline $\begin{array}{l}\text { Stroke Risk Factors } \\
\text { - Stroke History } \\
\text { - Hypertension } \\
\text { - Smoking } \\
\text { - Diabetes } \\
\text { - Hyperlipidemia } \\
\text { - CAD } \\
\text { - AF } \\
\text { - Family History }\end{array}$ & $\begin{array}{c}50(27.5) \\
116(63.7) \\
53(29.1) \\
69(37.9) \\
38(20.9) \\
58(31.9) \\
37(20.3) \\
55(30.2)\end{array}$ & $\begin{array}{c}26(37.7) \\
51(73.9) \\
13(18.8) \\
21(30.4) \\
16(23.2) \\
18(26.1) \\
10(14.5) \\
17(24.69)\end{array}$ & $\begin{array}{l}0.07 \\
0.10 \\
0.08 \\
0.22 \\
0.50 \\
0.50 \\
0.26 \\
0.33\end{array}$ \\
\hline $\begin{array}{l}\text { Consciousness Level } \\
\text { - Normal } \\
\text { - Somnolence/Stupor }\end{array}$ & $\begin{array}{c}129(70.9) \\
53(29.1)\end{array}$ & $\begin{array}{l}56(81.2) \\
13(18.8)\end{array}$ & 0.09 \\
\hline $\begin{array}{l}\text { Transfer to Hospital } \\
\text { - Ambulance } \\
\text { - Other }\end{array}$ & $\begin{array}{c}126(69.2) \\
34(49.3)\end{array}$ & $\begin{array}{l}56(30.8) \\
35(50.7)\end{array}$ & $0.005^{*}$ \\
\hline $\begin{array}{l}\text { Arrival to Hospital } \\
\text { - Direct Arrival } \\
\text { - Transfer from another } \\
\text { Center }\end{array}$ & $\begin{array}{l}130(71.4) \\
52(28.6)\end{array}$ & $\begin{array}{l}49(71) \\
20(29)\end{array}$ & 0.98 \\
\hline $\begin{array}{l}\text { NIHSS } \\
\text { (During application) }\end{array}$ & $5(1-32)$ & $3(1-17)$ & $0.01 *$ \\
\hline $\begin{array}{l}\text { Information about } \\
\text { thrombolytic therapy }\end{array}$ & $14(7.7)$ & $2(2.9)$ & 0.15 \\
\hline
\end{tabular}


Table 4. Multivariable logistic regression analysis

\begin{tabular}{|l|c|c|c|c|}
\hline & Wald & \multirow{2}{*}{-value } & OR & $\mathbf{\% 9 5 ( G A )}$ \\
\cline { 5 - 6 } & & & & Min \\
\hline Gender(female) & 6.92 & 0.009 & 2.21 & 1.22 \\
\hline Transportation & & & & \\
\hline Private vehicle & 3.32 & 0.068 & 1.80 & 0.96 \\
\hline Other & 0.02 & 0.867 & 1.10 & 0.31 \\
\hline NIHSS & 10.37 & 0.001 & 0.91 & 0.85 \\
\hline
\end{tabular}

OR: Odds ratio, CI (Confidence Interval)

$(\mathrm{mRS}$ score $\mathrm{mRS} \leq 2)$ in 140 patients $(55.7 \%)$ and poor functional outcome in 111 patients $(44.3 \%)$ ( $\mathrm{mRS}$ score $>2$ ) were observed during discharge. Stroke-related features of the patients are reflected in Table 2. In comparing the socio-demographic and clinical characteristics of the patients according to the time of arrival, female gender $(\mathrm{p}<0.03)$, having a low NIHSS score $(\mathrm{p}<$ $0.03)$ and not using ambulance in transportation $(\mathrm{p}<$ 0.03 ) affect the time of arrival to the hospital adversely (Table 3).

In the multivariable logistic regression analysis model, effective factors like gender, transportation to hospital and NIHSS variables were included, and the results of the analysis are presented in Table 4. The logistic regression model was found significant $(\mathrm{p}<$ 0.001 ) and the data set was seen to be compatible with the model $(p=0.587)$. When the table is examined, women have a 2.21 times higher risk of late admission to the hospital than men. The mode of transportation could not be determined as a risk factor on the duration of the arrival, and an increase in one unit to be observed in the NIHSS score reduced the risk of late arrival to the hospital by $9 \%$.

\section{DISCUSSION}

In our study, we examined the conditions causing a delay in the period from the onset of stroke to the arrival of patients at a training and research hospital with a stroke center. We found that 182 patients $(72.5 \%)$ arrived to the emergency ward of our hospital in the first 4.5 hours after the onset of the symptoms.

In the study carried out in Turkey by Memis et al. (4), $67 \%$ of the patients were reached the hospital diagnosed with acute ischemic stroke and in the study conducted by Guveli et al. (5) 30.7\% of them reached the hospital within 3 hours after the onset of stroke symptoms. In another research supervised by Kocak et al. (6), $29.5 \%$ of patients reached the hospital $\leq 4$ hours. In the study of Atay (22) in the district hospital, it was reported that $44.4 \%$ of the patients applied to the hospital within the first three hours and $48.9 \%$ within the first 4.5 hours of the treatment period. Dimitriou et al (19) stated in their study that $68.7 \%$ of the patients were diagnosed with acute ischemic stroke, in the study conducted by Fladt et al. (23), 58\% were reported to have applied to the hospital within the first 4.5 hours. In a city such as Bursa, where the traffic density is high and distances are remote, both public and healthcare staff trainings in favor of early treatment intervention may have played a role in the high rate of patients arriving within the first 4.5 hours. In addition, due to the fact that our hospital has been recognized as a stroke center, acute stroke patients can be primarily brought directly to our hospital by emergency medical service. This proves us that as long as a rapid in-hospital organization can be provided, eligible patients will not miss the chance to undergo thrombolytic therapy.

In some scientific studies, low income level has been reported as a factor related to the delayed arrival of patients with acute stroke (7). In some of the studies, no relation was observed between the income status and arrival at the hospital (8). In our study, we could not see a relationship between the income status and the arrival of the patients.

The relationship between the education level and the arrival time was also examined. In some studies, it was found that the level of education was low and this delayed the arrival of patients $(7,8,9)$, and in some, there was no relationship between these two factors $(10,11,12)$. In our study, no relation was found between the education level and the arrival of patients.

Another remarkable point in our study was that the distance was not related to a delay in arrival. Ashraf et al. (8) and Arulprakash et al. (12) found a distance of $15 \mathrm{~km}$ to the hospital was linked with a delay in transportation to the hospital in acute stroke patients. In another study by Nepal et al. (7), > $20 \mathrm{~km}$ distance was associated with a delay.

Arulprakash et al. (12) reported that urban residents were more likely to arrive to the hospital earlier, but we did not find residing in a city as a significant factor for early arrival. This may be due to the information provided to the patients and their relatives in advance and far-flung and vigorous effort of the emergency service teams throughout the city.

In the literature, some studies have found that female gender affects the time of arrival to the hospital (13-16) adversely, while some studies have stated that female gender affects hospital arrival $(8,17)$ positively. In some studies, there was no relationship between these two factors $(9,11,12)$. In our study, we figured out that female gender affects the time of arrival to the hospital adversely. This may be due to the absence of a family member during the day who would activate the ambulance service while many of the patients are at 
home alone or dealing with children or household chores. The fact that stroke cases in males are more frequent during the daytime, when they are actively involved in work life and socialized, may explain the early access to the hospital due to the presence of another person to call the ambulance directly.

In previous studies, using ambulance/emergency medical service has been shown to shorten the arrival time to the hospital $(10,13,14,15,18,19)$. The rate of ambulance use in acute stroke cases was reported to be $16.3 \%$ in the study of Memis et al (4) carried out in Aydin in our country. In the study conducted by Tekin Guveli et al. (5), the rate of ambulance use was reported as $30 \%$. In these studies, the absence of using an ambulance in acute stroke cases was associated with delayed arrival at the hospital, similar to our study. In our study, 160 (63.7\%) patients who were diagnosed with acute ischemic stroke were transferred to our hospital by ambulance. This rate shows that Emergency Health Services Ambulance System (112) is well organized in our city and the referral chain works regularly.

There are studies in the literature showing that the onset of the stroke symptoms at night delay the arrival of the hospital compared to the onset of daytime (7, $20)$. In our study, no relation was observed between the onset of symptoms as day and night and the time of arrival at the hospital.

Nepal et al. and Ashraf et al. $(7,8)$ stated that presence of stroke in patients' history did not shorten the arrival time to the hospital as in our study. This proves that there is a serious lack of awareness of stroke symptoms even in stroke patients. Training these patients and their relatives in recognizing the symptoms in hospital discharge and citing the importance of avoiding pre-hospital delays may reduce such hold-up situations.

Although some studies have found a link of a history of coronary heart disease related to early arrival at the hospital $(8,10)$, we did not detect a statistically significant relationship between the presence of stroke risk factors in the history such as hypertension, diabetes, coronary heart disease, and hospital arrival time.

We figured out that both lack of consciousness and low NIHSS score $(p<0.03)$ negatively affect the arrival time in our patients. In the literature, there are studies reporting that stroke duration of patients who are in a coma is shorter than other patients $(10,21,23)$. This may be due to the vigorous efforts of the relatives to deliver their patients with serious clinical conditions to a healthcare facility speedily. One of the remarkable points was that transfer from another center in our study was not a factor affecting the arrival time at the hospital. In some studies, it has been stated that the patient's first contact with the local doctor and the referral from another center is a cause linked with late arrival at the hospital $(7,8,23)$.

Our study also contains some limitations. It may not be generalized because it represents a training and research hospital experience with a stroke center and the sample size is small. In addition, it included patients or relatives who were diagnosed with ischemic stroke and who agreed to participate in the study. These are the limitations of this research. Therefore, further studies involving more centers are required.

\section{CONCLUSION}

In conclusion, comparing the socio-demographic and clinical features of the patients according to the time of arrival at the hospital we can state that female gender $(p<0.03)$, low NIHSS score $(p<0.03)$ and the absence of an ambulance in transportation $(\mathrm{p}<0.03)$ affect the time of arrival to the hospital adversely. In this respect, identifying these factors can also guide us in terms of solving problems resulting from time. This study also aims to increase the awareness of the use of emergency medical services.
Abbreviations
NIHSS - National Health Stroke Scale
mRS - Modified ranking scale
DM - Diabetes mellitus
CAD - Coronary artery disease
AF - Atrial fibrillation
OR - Odds ratio
CI - Confidence Interval

Conflict of Interests: The authors declare that there are no conflicts of interest related to this article.

Funding: None

\section{Licensing}

This work is licensed under a Creative Commons Attribution 4.0 International (CC BY 4.0) License. 


\title{
Sažetak
}

\section{FAKTORI KOJI UTIČU NA VREME PRIJEMA U BOLNICU PACIJENATA SA AKUTNIM ISHEMIJSKIM MOŽDANIM UDAROM}

\author{
Haki Cemile, ${ }^{1}$ Cetiner Mustafa, ${ }^{2}$ Kaya Halil ${ }^{3}$ \\ 1 University of Health Sciences, Bursa Yuksek Ihtisas Training and Research Hospital, \\ Department of Neurology, Bursa, Turkey \\ ${ }^{2}$ Kutahya University of Health Sciences Faculty of Medicine, Department of Neurology, Kutahya, Turkey \\ ${ }^{3}$ University of Health Sciences, Bursa Yuksek Ihtisas Training and Research Hospital, \\ Department of Emergency Medicine, Bursa, Turkey
}

Uvod: Poznato je da intravenska trombolitička terapija kod ishemisjkog moždanog udara je od koristi kod odabranih pacijenata koji se jave u toku prvih 4,5 sata nakon pojave simptoma i efikasnost tretmana zavisi od brzog prijema u bolnicu. Što je više prijema pacijenata u ovom vremenskom okviru, veća je i šansa da će primiti trombolitičku terapiju. Cilj studije je da ispita faktore koji su uzrok kasnog prijema pacijenata sa ishemijskim moždanim udarom.

Metod: U studiju su uključeni pacijenti koji su se javili u neurološku ambulantu i hitnu službu u periodu između februara i maja 2019. i dijagnostikovan im je akutni ishemijski moždani udar. Sproveden je odgovarajući direktni intervju kako bi se ispitali faktori koji su odlagali dolazak pacijenata ili rođaka pacijenata u Bursa Yuksek Ihtisas Training and Research Hospital zbog moždanog udara. Prema vremenu dolaska u bolnicu nakon pojave simptoma moždanog udara pacijenti su podeljeni kao rani $(\leq 4,5 \mathrm{sati}) \mathrm{i}$ kasni dolazak $(>4,5 \mathrm{sa}-$ ti). Na osnovu ovog grupisanja, faktori koji izrokuju

\section{REFERENCES}

1. Feigin VL, Forouzanfar MH, Krishnamurthi R, Mensah GA, Connor M, Bennett DA, et al. Global Burden of Diseases, Injuries, and Risk Factors Study 2010 (GBD 2010) and the GBD Stroke Experts Group. Global and regional burden of stroke during 1990-2010: findings from the Global Burden of Disease Study 2010. Lancet. 2014; 383(9913): 245-54.

2. Lahr MM, Luijckx GJ, Vroomen PC, van der Zee DJ, Buskens E. Proportion of patients treated with thrombolysis in a centralized versus a decentralized acute stroke care setting. Stroke. 2012; 43(5): 1336-40.

3. Emberson J, Lees KR, Lyden P, Blackwell L, Albers G, Bluhmki E, et al. Effect of treatment delay, age and stroke severity on the effects of intravenous thrombolysis with alteplase for acute ischaemic stroke: a meta analysis of individual patient data from randomised trials. Lancet. 2014; 384(9958): 1929-35.

4. Memis S, Tugrul E, Evci ED, Ergin F. Multiple causes for delay in arrival at hospital in acute stroke patients in Aydin, Turkey. BMC Neurol. 2008; 8:15.

5. Tekin Guveli B, Yatmazoglu M, Acar E, Senadım S, Coban E, Dayan C, et al. Pre-hospital obstacles in thrombolytic therapy and suggested solutions. Turkish Journal of Cerebrovascular Diseases. 2015; 21(3): 194-97. kašnjenje u dolasku pacijenata u bolnicu su statistički poređeni.

Ukupno 251 pacijenata i/ili rođaka pacijenata koji su došli u prijemnu neurološku ambulantu su intervjuisani. Od 251 pacijenata uključenih u studiju, 119 $(47,4 \%)$ je bilo ženskog pola i prosečne starosti 70 (34-94) godina. Od prilike 72,5\% pacijenata se javilo u bolnicu u toku prvih 4,5 sata od pojave simptoma moždanog udara. Faktori koji su uzrokovali kasniji dolazak u bolnicu su ženski pol, nizak NIHSS skor i nekorišćenje ambulantnog vozila za transport.

Zaključak: Zbog kasnog dolaska u bolnicu 27,5\% pacijenata, nije bilo moguće primeniti trombolitičku terapiju kod onih koji su ispunjavali uslove za nju. Kao faktori koji su razlog kasnog dolaska u bolnicu otriveni su ženski pol, manje težak moždani udar i transport bez ambulantnog vozila. S tim u vezi, potrebni su treninzi orjentisani prema zajednici.

Ključne reči: ishemijski moždani udar, kasni dolazak u bolnicu, hitna služba, trombolitička terapija.

6. Kocak S, Dogan E, Kokcam M, Girisgin AS, Bodur S Limitations in thrombolytic therapy in acute ischemic stroke: Pak J Med Sci. 2012; 28(4): 586-90.

7. Nepal G, Yadav JK, Basnet B, Shrestha TM, Kharel G, Ojha R. Status of prehospital delay and intravenous thrombolysis in the management of acute ischemic stroke in Nepal. BMC Neurol. 2019; 19(1): 155.

8. Ashraf VV, Maneesh M, Praveenkumar R, Saifudheen K, Girija AS. Factors delaying hospital arrival of patients with acute stroke. Ann Indian Acad Neurol. 2015; 18(2): 162-6.

9. Chen CH, Huang P, Yang YH, Liu CK, Lin TJ, Lin RT. Pre-hospital and in-hospital delays after onset of acute ischemic stroke: a hospital-based study in southern Taiwan. Kaohsiung J Med Sci. 2007; 23(11): 552-9.

10. Jin H, Zhu S, Wei JW, Wang J, Liu M, Wu Y et al. Factors associated with prehospital delays in the presentation of acute stroke in urban China. Stroke. 2012;43 (2): 362-70.

11. Hong ES, Kim SH, Kim WY, Ahn R, Hong JS. Factors associated with prehospital delay in acute stroke. Emerg Med J. 2011; 28(9): 790-3.

12. Arulprakash N, Umaiorubahan M. Causes of delayed arrival with acute ischemic stroke beyond the window period of thrombolysis. J Family Med Prim Care. 2018; 7(6): $1248-52$. 
13. Saver JL, Smith EE, Fonarow GC, Reeves MJ, Zhao X, Olson D, et al. The "golden hour" and acute brain ischemia: presenting features and lytic therapy in $>30,000$ patients arriving within 60 minutes of stroke onset. Stroke. 2010; 41(7): 1431-9.

14. Tong D, Reeves MJ, Hernandez AF, Zhao X, Olson DM, Fonarow GC, et al. Times from symptom onset to hospital arrival in the Get with the Guidelines - Stroke Program 2002 to 2009 : temporal trends and implications. Stroke. 2012; 43(7): 1912-17.

15. Mandelzweig L, Goldbourt U, Boyko V, Tanne D. Perceptual, social, and behavioral factors associated with delays in seeking medical care in patients with symptoms of acute stroke. Stroke. 2006; 37(5): 1248-53.

16. Smith MA, Lisabeth LD, Bonikowski F, Morgenstern LB. The role of ethnicity, sex, and language on delay to hospital arrival for acute ischemic stroke. Stroke. 2010; 41(5): 905-09.

17. Lichtman JH, Watanabe E, Allen NB, Jones SB, Dostal $\mathrm{J}$, Goldstein LB. Hospital arrival time and intravenous t-PA use in US Academic Medical Centers, 2001-2004. Stroke. 2009; 40(12): 3845-50.

18. Inatomi Y, Yonehara T, Hashimoto Y, Hirano T, Uchino M. Pre-hospital delay in the use of intravenous rt-PA for acute ischemic stroke in Japan. J Neurol Sci. 2008; 270(1-2): 127-32.

19. Dimitriou P, Tziomalos K, Christou K, Kostaki S, Angelopoulou SM, Papagianni M et al. Factors associated with delayed presentation at the emergency department in patients with acute ischemic stroke. Brain Inj. 2019; 33(9): 1257-61.

20. Soto-Cámara R, González-Santos J, González-Bernal J, Martín-Santidrian A, Cubo E, Trejo-Gabriel-Galán JM. Factors associated with shortening of prehospital delay among patients with acute ischemic stroke. J Clin Med. 2019; 8(10): E1712.

21. Lee SJ. Association between Prehospital Delay Status and Stroke Severity in Acute Ischemic Stroke: Shift-Analysis Approach. J Nurs Care. 2018; 7:452. doi: 10.4172/2167-1168. 1000452.

22. Atay V. Acute stroke through the perspective of a county hospital: problems and opportunities. Turk J Neurol. 2016; 22(1): 13-8.

23. Fladt J, Meier N, Thilemann S, Polymeris A, Traenka C, Seiffge DJ et al. Reasons for Prehospital Delay in Acute Ischemic Stroke. J Am Heart Assoc 2019; 8(20): e013101.

\section{Correspondence to/Autor za korespondenciju}

Cemile Haki, MD

Adress: Mimar Sinan Mahallesi, Emniyet Cd, No: 3516310 Y 1ldırım/ Bursa, e-mail: cemilehaki@gmail.com

Telephone Number: 05324713151- 02242944000 